\title{
Multiculturalism and Socio-Cultural Conflicts in United Kingdom: A Critical Analysis
}

\author{
Barnabé B. Oladjehou ${ }^{1 *}$, Ibrahim Yekini ${ }^{2}$ \\ ${ }^{1}$ FLLAC/UAC (Bénin) \\ ${ }^{2}$ ENS Porto-Novo (Bénin)
}

*Corresponding Author: Barnabé B. Oladjehou, FLLAC/UAC (Bénin)

\begin{abstract}
This study aims to examine the phenomenon of multiculturalism and socio-cultural conflicts in United Kingdom. In fact, the concept of multiculturalism as the belief and practice of giving equal importance to each of the different culture in a society is a doctrine that recognizes ethnic diversity within a society and that encourages others to be enlightened by those of diverse ethnical and cultural background. The consequences of the socio-cultural conflicts handicap the success of this phenomenon, not only in the United Kingdom but all over the world. So, this study is significance since it can draw the attention of people on the studied phenomenon which remains nowadays the basic factor of most conflicts in the world.
\end{abstract}

\section{INTRODUCTION}

The United Kingdom is composed of many ethnic groups such as: English, Scottish, Irish, West Indian and Pakistani, all diversity of cultural backgrounds, religions, languages, life styles, and ideologies. Immigrants have started to arrive after that people from the former British colonies in South Asia have become part of today's multicultural British society.

The United Kingdom, dealing with all these people and cultural diversities usually face the opposition of some interpersonal relations and misunderstandings that from time to time lead to social conflicts. Furthermore, according to the official census of population of $29^{\text {th }}$ April 2001, the percentage of inhabitants of the United Kingdom living in England is 83, 60\%, Scotland 8,60\%, Wales 4,9\% of the population and 2,9\% of people living in the United Kingdom is setting in Northern Ireland (Official Census of Population of 29 April, 2001).Therefore, fewest of all, live in Wales, Scotland and Northern Ireland. This made England especially, full of the majority of the United Kingdom's diverse ethnic groups that made the country a multicultural society where the phenomenon of multiculturalism is based and social conflicts rarely lack. At this level, thinking about the success of multiculturalism in that melting pot, a bitter observation has drown our attention and has even shocked us: the quasi totality of ethnic groups within the same community reject their neighbour's cultural values, life styles which are thought to be different from their own.

The ideology of accepting others, whatever their social and cultural origins by living in the same society without getting in conflicts, lack in people's minds. This is worrying, according to its status of "four nations in one" and also, its status of multicultural society. In the United Kingdom, when there were disturbances involving violent conflicts between Asian and native British Citizens, such conflicts were diagnosed as due to the phenomenon of multiculturalism. Thus multiculturalism has become a general phenomenon that need to be studied in such a way to eradicate inter-cultural and social troubles that mostly represent the spreading danger which not only handicaps the moral and civic equality of the citizens but also the United Kingdom's own development. Through my analysis, I will discuss about British multiculturalism and how cultural diversity led to social clashes. During the discussion, I will basically focus my attention in finding the reason why the phenomenon of multiculturalism which aims to build a social house or social cohesion, elevate and celebrate diversity led to social clashes.

\section{Multiculturalism And Politics in The United Kingdom}

According to Taylor C "Britain has become a multi-ethnic, multi-faith society that needs to strengthen community cohesion, a concept that amalgamates various different communities ${ }^{1}$. This vision is one

\footnotetext{
${ }^{1}$ Taylor, C. "Multiculturalism and the politics of recognition ". University Press 1994, P34.
} 
that promotes standardization while erasing boundaries. For this reason, British politics have encountered a major challenge in dealing with the rights of minority groups and with issues of integration and community cohesion.

In the 1960s, the arrival of huge numbers of immigrants from the Commonwealth to Britain drew the attention of political parties that formed opinions and attitudes meant to maintain the support of their voters. These attitudes were not only meant to create voting power but also to mold views, which became ingrained in the majority white population's consciousness about the immigrant and his/her role within civil society in the U.K.

Multiculturalism has been the political and social solution offered with groups of different cultures and religions being offered rights and opportunities to live in Great Britain.

In this context, Prime Minister Tony Blair re-asserted the importance of the rights and responsibilities of the citizens in relation to the state.

"He sees it as a contract in which the citizen enjoys the rights and opportunities offered by the state while being aware of his/her responsibilities and obligations" 2 .

This contract is one based on respect and self-respect, the basis of a healthy community. Civil society is built on mutual respect and it needs re-find the "moral fabric of community". By emphasizing community, Tony Blair empowers the state and national identity over ethnic identity. By doing this, he resorts to the idea of liberation, a liberation which every citizen deserves. The modality to create such an enabling state is by equalizing opportunity, rebuilding cohesive communities and reforming the criminal justice system.

After Tony Blair, Prime Minister David Cameron points directly to the threat - terrorist attacks rooted in Islamist ideology. Trying to be politically correct, Mr. Cameron differentiates in his speech17 from 2011 given in Munich between Islamist extremism and Islam, wishing not to offend those who embrace Islam as a religion: "Islamist extremism and Islam are not the same thing", Said Cameron.

Cameron even specifies that he rejects the extreme Right opinion according to which 'Islam and the West are irreconcilable'. David Cameron links terrorism with Muslims. His greatest concern, evidently in view of the 2005 attacks, derives from the threats that come from within the country rather than from outside it, for which reason he points to "young Muslims". Cameron brings up the issue of identity, asserting that these "young Muslims" find it hard to identify with both traditional Islam and with Britain, thus assuming an inherent hyphenated identity in their case. This hyphenation is also assumed by Mr. Cameron to be generative of opportunities for these people to develop an entire and unique religious identity, joined by radical beliefs, as Mr. Cameron himself asserts, beliefs that ultimately turn into violence. This is possible, he continues, because of an attitude of "passive tolerance" on the part of the state that is because of multiculturalism. Thus, he suggests that the state be more active and asserts that "state multiculturalism has failed".

If one can notice the evolution of political views in Britain with regard to immigration in general and to Muslim immigrants in particular, the discourse has become more inclusive of diversity while denying difference as a disturbing element generative of group isolation and disrupting community cohesion. Political figures such as Tony Blair and David Cameron disguise their encouragement towards cultural assimilation by using metaphors: Blair uses the contract metaphor in which the citizen and the state offer each other mutual respect; Cameron offers to provide "young Muslims" a more accessible and a clearer idea of belonging to the Nation. Mr. Cameron's idea of belonging is defined in Western cultural terms - freedom of speech, freedom of worship, and democracy, among others, thus disregarding an idea of belonging that is different from the one included in the Western discourse.

In his article "Cultural Diversity and Cultural Differences", Homi K. Bhabha

"Sides with the perspective that enables cultural difference as a necessary element in the maintenance of a diverse, multi-cultural society as, should difference be blurred or erased, uniformity would take its place"3

Bhabha pleads for cultural difference and for a fluid, changing idea of identity, one that cannot be defined only in national terms. He also insists on fighting uniformisation as a form of resistance as

\footnotetext{
${ }^{2}$ Blair, Tony. The Courage of Our Convictions. Fabian Society London, UK. 2002.

3 Homi Bhabha : «Cultural Diversity and Cultural Differences”, London. 1995.
} 
well as a form of progress; the diversity of cultures and religions that co-exist in certain spaces creates a challenge for those who live there, it puts pressure on those individuals to negotiate space and culture and to learn how to live in proximity with one another.

This situation can be generated by a potential losing of the thing, the nation becomes aggressive or even violent towards the potential threat.

\section{SOCIO-CULTURAL MANIFESTATIONS IN THE UNITED KINGDOM}

In severely divided societies, ethnicity finds its way into a myriad of issues: development plans, educational controversies, trade union affairs, land policy, business policy, tax policy. Characteristically, issues that would elsewhere be relegated to the category of routine administration assume a central place on the political agenda of ethnically divided societies.

This is certainly the case in the United Kingdom, where every public issue becomes a focus of ethnonational conflict. "Before the Troubles began, the key issues were housing, job discrimination and political gerrymandering.

For Trust R, "As the conflict intensified, these issues ail became entangled within the wider ethnonational conflict" ${ }^{4}$. This is one of the features that make that conflict so complex and enduring. It permeates the very fabric of society. This complexity is highlighted as a severe hindrance to conflict resolution. The emergence of multiculturalism in Britain occurred simultaneously with these ambiguous post-colonial reconstructions as the 'non-white' immigration from the Commonwealth started.

The concept of "multiculturalism was introduced gradually to the British society from the early 1970s as a third response to cultural differences after assimilationist and integrationist policies. Multiculturalism was also a response to the newly emerging second and third generation ethnic minority pupils from Commonwealth countries. Moreover it was the result of desperate search for a solution of growing anti-racist movements, which were a response to ' the far right groups such as National Front, to racial attacks and oppressive policing.

The United Kingdom is made up of four interdependent nations with many common institutions. While differences in everyday modes of sociality and consumer behavior are not great from one part of the nation to another, some aspects of culture are symbolic of national $\mathrm{f}$ or local difference on the level of everyday practice or on special occasions. Support for the monarchy, political parties and soccer teams are the most obvious expressions of contemporary localism; religious adherence and ethnic differentiation are also significant. Support for the monarchy and the conservative party is highest in England especially in the south, while in Scotland and Wales it is substantially lower.

"In Scotland and Wales, there are minority nationalist parties. The Scottish National Party's political program is dominated by economic issues, particularly tax revenues from North Sea oil. The political agenda of the Welsh nationalist party is mainly concern with linguistic and cultural matters. In both Scotland and Wales, the Labour Party is dominant, drowning strength from its critique of the class privilege traditionally associated with London and southeastern England.

A high degree of special integration is generally held to be indicative of social integration, assimilation, and acculturation, while special segregation is indicative of social pluralism. NonEuropean immigration in Britain has not moved toward a pattern of sharply-defined urban ethnic ghettoes. Nevertheless, many non-European immigrants continue to be subject to discriminatory practices in employment, education and in other spheres, even if systematic marginalization cannot be inferred from their special distribution within the towns and cities of the nation.

In the educational sphere, spatial segregation of the different cultural groups combined with the increased promotion of the faith schools by the government, brought in turn an inevitable segregation in schooling and education. Passing through an assimilationist education policy that was commonly deemed as unsuccessful in countering racism, multiculturalist education policies were motivated by the question of how to create a tolerant educational environment for non-white minorities in a white dominated nation. In that context intolerance is perceived as deriving from prejudice. In her work,

\footnotetext{
${ }^{4}$ Runnymede, Trust. The Future of Multi-ethnic Britain (The Parekh Report).London:2000. P48.
} 
Harris states that: "the promoters of multiculturalists 'education thought that intolerance can be overcome by a basic educational program that is: sympathetic teaching of "other cultures" ${ }^{5}$

The specific programs on teaching to value and respect cultural heritage of own and other ethnic minorities were developed. However the promoters of the concept failed to see that, ethnic cultural formations are too complex to be reduced to festivals, religions and lifestyles. Thus multiculturalists 'education failed to acknowledge the "embeddedness" of racism and discrimination in structures and institutions. Schooling also proved a major factor in determining people's friendship circles. Even though only around seven per cent of children are privately educated and the survey found that most people who went to independent schools mainly, socialize with others who also did. Six out of 10 of those polled who said that they went to independent schools admitted that the majority of their friends did so too. British people need policies actively to promote integration, rather than foster segregation and ultimately lead to greater social isolation, since the Multiculturalist education that was introduced to reduce racism by teaching difference failed its aim, and sets the hegemonies white majority culture as the norm.

Today, in the United Kingdom as in other countries populated largely by immigrants, the culture is influenced by the many groups of people (religious groups or ethnic groups) that now, with the diversity of their languages and religions make up the country, a multi-cultural and multi-ethnic society. The main ethnic groups living in the United Kingdom are English, Scottish, Irish, Welsh, West Indian and Pakistani. Among the above ethnic groups, some are immigrants. "Immigration into the United Kingdom reached a peak at the end of the 1950s when the British economy needed more people to fill largely unskilled jobs. Indeed, there are millions of people who came from former overseas colonies. This immigration consisted primarily of immigrants from British Commonwealth countries: we have West Indian from the Caribbean, Blacks Africans from East Africa and West Africa, Indians, Pakistanis and Bangladeshis from the south Asian sub-continent (what used to be India before Independence). We also have the Chinese Ethnic group or Chinese British from China and other South-East Asian countries. There are other ethnic group including Europeans especially from central and Eastern Europe including Jews escaping Nazism and later communist régimes. According to the office for national statistics (ONS), ethnic minorities tend to live in England, with just 3\% of them living in Scotland, Ireland or Wales. Fewest of ail live in Scotland where just 1.7\% of the people said that they belonged to a minority ethnic group. According to the official census of population of $29^{\text {th }}$ April 2001, Most inhabitants of UK live in England (83.6\%), 8.6\% lives in Scotland; Wales is home to $4.9 \%$ of the population and $2.9 \%$ of people living in the UK is setting in Northern Ireland. Apart from the ethnic groups, there is a diversity of religions in UK.

Most of the population said they were Christians. Among these people were the protestant majority in Northern Ireland (1 million Protestants, half a million Catholics) who immigrated to Scotland, which account for the large catholic community. After the Christianity, Islam was the most common faith of people describing themselves as Muslim. Some are Hindu, Sikh, Jewish, Buddhist. Apart from these, there are other religions. People in Northern Ireland were most likely to say that they are identified with religion compared with those in England, Wales and Scotland. Agnostics and Atheists stated that they had no religion. As it's already mention above, we notice that a large majority of people consider themselves to be Christians. These are divided Protestants, made up mainly of the Church of England. Muslims (Islam) from the largest non-Christian community (mostly from Pakistan\& Bangladesh), others being Hindus (Hinduism), Sikhs (Sikhism), Jews (Judaism ), and Buddhists (Buddhism).Therefore, due to the immigration, we notice that the United Kingdom is increasingly multi-ethnic, which means that it is more multi-faith country in which a diversity of languages are spoken.

The United Kingdom's official language is English .Welsh and Celtic language from the

Indo-European family is spoken by a quarter of the population of the Wales and is the first language of the welsh .Gaelic, the language of Celts in Scotland and Ireland is spoken by people in Scotland especially in the Western High lands, where it is the mother tongue of a very small percentage of inhabitants. A variety of other languages are spoken by Asian Britons, including Bengali, the official language of Bangladesh; Gujarati, the state language of Gujarat; Hindi, a language or a group of

\footnotetext{
${ }^{5}$ Harris, Colette "Beyond multiculturalism. Difference, recognition and social justice" in Patterns of prejudice, London, 2001.P132.
} 
dialects of North central India; Punjabi, the state language of Punjab, North West Indi and Urdu, an official language of Pakistan also spokenin Indian. Other prominent minority languages spoken in the United Kingdom include Arabic and Chinese. This diversity of ethnic groups, religion and languages in the United Kingdom gave birth to the phenomenon of multiculturalism.

In Britain today, communities live side by side with people from different ethnic, cultural, social, and religious background. People are becoming increasingly aware of the fact of living in a multi-ethnic and multicultural society. Depending upon where they live, work, or which services they access in the community, people have probably seen changes to their communities over a period of time. They are increasingly aware of the differences and similarities among themselves and others, in relation to: age, gender, ethnicity, culture, religious beliefs and practices, social and economy status, educational and occupational backgrounds, disability, sexual orientation, health and so on. The pattern of migration and the reasons for migration determine how people perceive themselves in relation to the new environment and their experiences within the prevailing culture. As time moves on, children of migrant who are born in the adopted country develop their own identities with respect to the country they live in:

"Their values, beliefs, experiences and aspiration are in part shaped by the prevailing culture. However, in many instance, migrant adopt from communities that reflect some collective values, beliefs, and lifestyles of the culture they left behind. Communities emerge, centered on the ethnic and cultural identity that people hold. Therefore, children of immigrant are often in contact to different cultural values"6.

We can note many ethnicities and many communities in Britain today. Children born to parent who are from missed ethnic and cultural backgrounds further highlight the accelerated transition that ethnic and cultural identities have undergone. Family life is changing, and there are tensions between kinship ties and some contemporary social values. However, the great majority of people perceive themselves to be part of multigenerational families and regard these relationships as very important.

\section{BRitish MulticulturaliSM ANd CUltures}

The cultures of England, Scotland, Wales and Northern Ireland are diverse and have varying degrees of overlap and distinctiveness. The culture of the United Kingdom is the pattern of human activity and symbolism associated with the United Kingdom and its people. It is influenced by the UK's history as a developed island country, a liberal democracy and a major power, its predominantly Christian religious life, and its composition of four countries: England, Northern Ireland, Scotland and Wales; each of which has distinct customs and cultures.

British cultures are the totality of socially transmitted behavior patterns, arts, beliefs, institutions, and all other products of human work and thought. In other world, British cultures are the characteristics of British population, defined by everything from language, religion, social habits, music and arts. Ethnic groups are the images of the British cultures represented by category of the population that, in a larger society, set apart or bound together by common ties of race, language, nationality, or culture. In order word, these ethnic groups are the set of population with the same race or nationality who share a distinctive culture.

According to the term of cultures, the UK's societies are becoming more homogenous with different elements melting-together into a harmonious whole with a common culture ; this describes the assimilation of immigrants ; and the melting pot model of culture in the UK was challenged by proponents of multiculturalism, who assert that cultural differences within society are valuable and should be preserved, proposing the alternative metaphor of the mosaic (different cultures mix, but remain distinct). In fact, the cultural mosaic is a term used to describe the mix of ethnic groups, languages and cultures that co-exist within a society. This idea of a cultural mosaic is intended to champion an ideal of multiculturalism, differently from other systems like the melting pot, which is often used to describe the neighboring multicultural societies' ideal of assimilation.

The phenomenon of multiculturalism is at the origin of the construction of the social housing which one supposes being a corrective measurement for segregation and discrimination. However it is noted that via this social housing settles conflict relations between the various ethnics groups gathered in the

\footnotetext{
${ }^{6}$ Op.Cit P46.
} 
same crucible or the same space of life. The social house, known in other word as a social cohesion is increasingly a high priority on the policy agenda not only in the United Kingdom but indeed globally. This upsurge of interest in social cohesion and social education, especially in ethnically and religiously diverse societies, can be seen in both multination states, and multicultural states that have witnessed large-scale immigration. In such contexts of internal division, whether this devolution, increased social pluralism or civil conflict; policy discourses are advocating a "common »" or national social cohesion. The promotion of a common 'multicultural community" and the policy concept of "community cohesion" are typically presented as key aims of social cohesion education policy.

Multicultural society is where a variety of many different cultural/ethnic groups live together within the same society. In a multicultural society, there is not an official culture that every person must be a part of. Instead, all cultures are respected as much as each other. In general, a multicultural society is formed when people from many different countries all migrate to one place. For example, $10 \%$ of the UK's population consists of different racial groups and multicultural cities are called cosmopolitans. If we walk down any bustling London stress, it is likely we come across many people from different cultural backgrounds. Currently, over 200 languages are spoken in London and the diversity of different cultures within London is so great that easy definition is impossible. The city is home to over three hundred nationalities that have over time molded and shaped London's culture to what it is today.

Multiculturalism, for its part, developed out of the belief that group marginalization often has yet deeper origins. It is not merely a legal, political or social phenomenon but is, rather, a cultural phenomenon, one that operates through stereotypes and values that structure how people see themselves and are seen by others. Universal citizenship and equality of opportunity, in other words, do not go far enough. Egalitarianism, in both its legal and social forms, has limited value, and may even be part of the problem. Multiculturalism, by contrast, is distinguished by an emphasis on difference over equality. This is reflected in its central theme: a positive endorsement, even celebration, of cultural difference, allowing marginalized groups to assert themselves by reclaiming an authentic sense of cultural identity. Multicultural rights are therefore specific to the group concerned, as opposed to 'equal' or 'universal' rights.

They include: the right to (public) recognition and respect. There, cultural groups, defined by characteristics such as religion, language, ethnicity or national origin, should somehow be accepted as legitimate actors in public life. Such rights may include the right not to be offended, protecting the sacred or core beliefs of a group from being attacked or insulted.

Minority, 'special' or 'polytechnic' rights. These are legal privileges or exclusions that enable particular cultural groups to maintain their identities and their distinctive ways of life.

The right, in certain circumstances, to some degree of self-determination. For the purpose of this study's analysis, I suggest to disaggregate the complex phenomenon of multiculturalism along three dimensions : first, multiculturalism as a challenge to the premier cultural community of the modern world ; second, multiculturalism as a quest for recognition and compensatory treatment of disadvantaged and discriminated group in society (minorities) ; and third, multiculturalism as a generalized from of anti-colonial discourse and struggle. With regard to the first dimension, the very notion of multiculturalism conveys that not one but multiple cultures coexist within a limited, statebounded territory.

\section{British Socio-Cultural Clash}

The socio-cultural cash is a difference that makes it difficult for people within the same country, society or world to be together and work together. This disagreement between people usually makes them in a situation in which they are fighting or disagreeing to come into conflict with one another and unfortunately, hundreds of people were often killed during ethnic classes.

Many people in Britain consider immigration to me one of the most important issues facing the country today. Their concerns seem to be as much about the social impact of immigration as its economic impact, which economists typically conclude are small. It is not entirely clear what social consequences of immigration are feared. Sometimes, it is simply the dilution of traditional culture; sometimes it is a more melodramatic fear that Britain is becoming a mix of mutually incompatible cultures, whose irreconcilable differences could end in a serious 'culture clash'. In UK for instance, 
there is a widespread belief that a growing fraction of Muslim who lives (and in many cases were born) in Britain, do not think of themselves as British, have no aspiration to do so and not want their children to do so either. Instead, it is feared, they subscribe to some other identity, creating little enclaves that resemble, as far as is possible, the countries from which they came o a model of a good society very different from what is generally thought of as 'Britain'. Such fears tend to be magnified by the statements by some British Muslims, which appear explicitly to reject a British identity and affirm another one.

At this case, it is important to outline that a multicultural society should remain society where cultural diversity and coexistence should be endorsed and where legal mechanisms should be set in place to protect " otherness".

Multiculturalism has failed to create an inclusive society, while the ghettoization of Britain is hindering cultural and intellectual fusion. At that extend, we must look again at the balance of rights and responsibilities of minority groups.

The existing perception and enforcement of multiculturalism is hindering social integration in Britain. The slow process of social integration, which is caused by some multicultural policies, is intensifying the fragmentation of British society, thereby jeopardizing the future of diversity in Britain. Multiculturalism promised to bring social inclusion, but has failed and is becoming a justification for exclusion. Instead of accommodating the positive aspects of diversity, it has paved the way for ghettoization of Britain, which is based on class, race, and religion.

Although multiculturalism is associated with tolerance and social pluralism, it is sometimes used as an excuse to justify social division and segregation in Britain. It is difficult to avoid the fact that under the umbrella of multiculturalism, some socio-cultural groups exist in their own bubbles, completely separated from the mainstream. By confining themselves to these social bubbles, they actively enforce their own exclusion. In an excluding social framework that is indifferent to the prevailing narratives of the mainstream culture, there is no ground for responsibility to grow.

The current model of multiculturalism has minimized the platforms for social dialogues through which we can address deep social cultural issues. If the minorities are resorting to the ghettos, where can cultural and intellectual fusion take place? Even the British education system, which is supposed to be the last bastion for disparate social narratives to harmonize, has in some cases become the very instrument to enforce division and exclusion. Year by year, the government have justified faith schools where children have to internalize their "differences", all in the name of multiculturalism. Many of the immigrant children who do not attend faith schools still attend what we would call 'race schools". Throughout the country, there are many schools predominantly populated by certain ethnic compositions to which white families avoid sending their children. The British education system has failed to go beyond the obstacles of class, race, and religion and has failed in diversifying the educational institutions to promote socio-cultural fusions.

Exclusion and ghettoization of Britain are increasing the levels of mistrust and fear, a process which will only deepen the schisms in among communities. In such situations, the culture of political correctness becomes an instrument of social control to prevent social disruption in the short term. Having a more politically correct society does not mean that people have become more tolerant. The merit of tolerance is to prevent exclusion. Hence, if the current model of multiculturalism in Britain still breeds segregation, then obviously something has gone wrong.

Naturally, no tolerant society based on liberal principles would ever attempt to standardize subcultures and impose conformity. Indeed, diversity could strengthen Britain from many perspectives. Nonetheless, this diversity only becomes valuable when there is dynamic social dialogue, when a subculture is actively engaged in a cultural exchange with the mainstream and when there is reciprocity. The current model of multiculturalism has largely failed to generate such dynamic social dialogue. Both the political system and the excluded communities have not done enough to translate the differences into cohesion and social strength. There is a limit to how far the culture of political correctness can prevent social conflicts. Thus, in order to actualize the positive potentials of diversity, new measures should be taken to address the repercussions of multiculturalism in Britain.

The socio-cultural clash is a difference that makes it difficult for people within the same country, society or world to be together and work together. This disagreement between people usually makes 
them in a situation in which they are fighting or disagreeing to come into conflict with one another and unfortunately, hundreds of people were often killed during ethnic classes.

Many people in Britain consider immigration to me one of the most important issues facing the country today. Their concerns seem to be as much about the social impact of immigration as its economic impact, which economists typically conclude are small. It is not entirely clear what social consequences of immigration are feared. Sometimes, it is simply the dilution of traditional culture; sometimes it is a more melodramatic fear that Britain is becoming a mix of mutually incompatible cultures, whose irreconcilable differences could end in a serious 'culture clash". In UK for instance, there is a widespread belief that a growing fraction of Muslim who lives (and in many cases were born) in Britain, do not think of themselves as British, have no aspiration to do so and not want their children to do so either. Instead, it is feared, they subscribe to some other identity, creating little enclaves that resemble, as far as is possible, the countries from which they came a model of a good society very different from what is generally thought of as 'Britain'. Such fears tend to be magnified by the statements by some British Muslims, which appear explicitly to reject a British identity and affirm another one.

At this case, it is important to outline that a multicultural society should remains society where cultural diversity and coexistence should be endorsed and where legal mechanisms should be set in place to protect "' otherness"'.

Multiculturalism has failed to create an inclusive society, while the ghettoization of Britain is hindering cultural and intellectual fusion. At that extend, we must look again at the balance of rights and responsibilities of minority groups.

The existing perception and enforcement of multiculturalism is hindering social integration in Britain. The slow process of social integration, which is caused by some multicultural policies, is intensifying the fragmentation of British society, thereby jeopardizing the future of diversity in Britain. Multiculturalism promised to bring social inclusion, but has failed and is becoming a justification for exclusion. Instead of accommodating the positive aspects of diversity, it has paved the way for ghettorisation of Britain, which is based on class, race, and religion.

Although multiculturalism is associated with tolerance and social pluralism, it is sometimes used as an excuse to justify social division and segregation in Britain. It is difficult to avoid the fact that under the umbrella of multiculturalism, some social group exists in their own bubbles, completely separated from the mainstream. By confining themselves to these social bubbles, they actively enforce their own exclusion. In an excluding social framework that is indifferent to the prevailing narratives of the mainstream culture, there is no ground for responsibility to grow.

The current model of multiculturalism has minimized the platforms for social dialogues through which we can address deep social cultural issues. If the minorities are resorting to the ghettos, where can cultural and intellectual fusion take place? Even the British education system, which is supposed to be the last bastion for disparate social narratives to harmonize, has in some cases become the very instrument to enforce division and exclusion. Year by year, the government have justified faith schools where children have to internalize their "differences", all in the name of multiculturalism. Many of the immigrant children who do not attend faith schools still attend what Ishould call "race schools". Throughout the country, there are many schools predominantly populated by certain ethnic compositions to which white families avoid sending their children. The British education system has failed to go beyond the obstacles of class, race, and religion and has failed in diversifying the educational institutions to promote socio-cultural fusions.

Exclusion and ghettoization of Britain are increasing the levels of mistrust and fear, a process which will only deepen the schisms in among communities. In such situations, the culture of political correctness becomes an instrument of social control to prevent social disruption in the short term. Having a more politically correct society does not mean that people have become more tolerant. The merit of tolerance is to prevent exclusion. Hence, if the current model of multiculturalism in Britain still breeds segregation, then obviously something has gone wrong.

Naturally, no tolerant society based on liberal principles would ever attempt to standardize subcultures and impose conformity. Indeed, diversity could strengthen Britain from many perspectives. Nonetheless, this diversity only becomes valuable when there is dynamic social 
dialogue, when a subculture is actively engaged in a cultural exchange with the mainstream and when there is reciprocity. The current model of multiculturalism has largely failed to generate such dynamic social dialogue. Both the political system and the excluded communities have not done enough to translate the differences into cohesion and social strength. There is a limit to how far the culture of political correctness can prevent social conflicts. Thus, in order to actualize the positive potentials of diversity, new measures should be taken to address the repercussions of multiculturalism in Britain.

\section{CONCLuSion}

Multiculturalism, as a philosophical concept, is seen as both a solution and a problem. On the one hand, it is praised for advancing equality and social recognition and on the other hand, it is criticized for creating inequality and social fragmentation. While philosophical and normative approaches, such as the ones briefly sketched above, are significant in outlining the institutional frameworks that can 'reconcile' difference and equality in the public sphere, I suggest that these need to be complemented by a grounded empirical approach to multiculturalism.

Multiculturalism is thus not just a framework that formally regulates inter-cultural relations but can be also seen as an everyday practice. We suggest that this empirical level of intergroup interactions and people's engagement with multiculturalism in the context of their everyday lives need to be studied alongside macro-level theorization of multicultural justice and citizenship.

In determining whether being in a multicultural society has more advantages or disadvantages, I must consider most, the advantages of the phenomenon of multiculturalism than the disadvantages. We can acquaint ourselves with other cultures and traditions promoted by other cultures. It's very important for example in art and music because we are searching new inspiration like mixing hip-hop with Arabian traditional songs. Also it's useful for cooks who are also interested in searching extraordinary flavors. In addition, studying other cultures has a wonderful influence on our minds. When Iam learning about them, I focus and practice my memory. Everything I see around me has been influenced in some way by different cultures. Our clothes, daily routine, music, food, art; sport and poetry are all as they are because they have been mixed with our knowledge of different cultural features. Through multiculturalism, we have opened our minds and have had the opportunity to learn about many different things: plus the country has benefited from it economically in many ways. What is more, living in such a society makes people more tolerant of each other, even if they are from very different backgrounds. However, because of fascination in foreign countries we can forget about ours. There are many cases when somebody abandoned cultivation of his, own traditions. I think it is very important that each people, to be proud of his religion and civilization and considers others without discriminate when living in a multicultural society. I can try new things but I can't forget old ones. It's our history and background. One, who doesn't know history, might do the same mistakes as his predecessors.

To sum up, while normative and philosophical conceptualizations of multiculturalism help us develop frameworks for equal participation in culturally diverse societies, these conceptualizations are somewhat idealistic and tend to overlook the dynamics, tensions and meanings associated with multiculturalism as it is actually lived. Social psychology can help us relate these issues to people's real experiences. In the context of growing uneasiness regarding multiculturalism across UK and other multicultural countries, it is imperative to develop a deeper understanding of how multiculturalism 'works' in practice in order to advance appropriate policies that are grounded in people's actual experiences.

\section{REFERENCES}

[1] Blair, Tony (2002). The Courage of Our Convictions. Fabian Society, (London, UK). 2002.

[2] Benhabib, Seyla .The Claims of Culture: Equality and Diversity in the Global Era, Princeton: Princeton University Press.2002.

[3] Donald, Horowitz, Conflict and the incentives to political accommodation', in Dermot Keogh and Michael H. Haltzel (eds.) Northern Ireland and the Politics of Reconciliation. Cambridge, University Press, 1994.

[4] Gilroy, Paul. After Empire: Melancholia or Convivial Culture? , London: Routledge .2004

[5] Habermas, Jurgen (2005) "Religion in public Sphere" in European Journal of Philosophy accessed through Google Books 2005. 
[6] Harris, Colette "Beyond multiculturalism? Difference, recognition and social justice" in Patterns of prejudice, 2001.

[7] Henri, Tajfel. Differentiation between Social Groups. London, Academic Press Inc., 1978.

[8] Hesse, B. Introduction' in Un/Settled Multiculturalism: Diasporas, Entanglements, Transruptions. London, New York: Zed books 2000

[9] Horowitz, Donald L. Ethnic Groups in conflict. Berkely, University of California Press, 1985.

[10] James Trotman C., Multiculturalism Roots and Realities, Indiana University Press Retrieved 29 January 2018.

[11] Kymlicka, W. Multicultural Citizenship. Oxford: Oxford University Press.1995.

[12] Modood, Tariq Post-Immigration 'Difference' and Integration: The case of Muslims in Western Europe, London: The British Academy, 2011

[13] Parekh, Bhikhu C. Rethinking multiculturalism: culture diversity and political theory, Harvard UP .2002

[14] Runnymede, Trust. The Future of Multi-ethnic Britain (The Parekh Report).London: Runnymede. 2000

[15] Seamus, Dunn, Facets of the Conflict in Northern Ireland. New York, St. Martin's Press, 1995.

[16] Susanne, Wessendorf, The multiculturalism backlash, European discourses, policies and practices, ; accessed through Google Books, .12 February2018

[17] Taylor, C. "Multiculturalism and the politics of recognition ". University Press1994

[18] Tariq, Modood; Anna, Multiculturalism Muslims and citizenship: a European approach. Routledge.6 April 2006.

Citation: Barnabé B. Oladjehou, Ibrahim Yekini. "Multiculturalism and Socio-Cultural Conflicts in United Kingdom: A Critical Analysis" International Journal of Humanities Social Sciences and Education (IJHSSE), vol 5, no. 12, 2018, pp. 128-137. doi: http://dx.doi.org/10.20431/2349-0381.0512013.

Copyright: (C) 2018 Authors. This is an open-access article distributed under the terms of the Creative Commons Attribution License, which permits unrestricted use, distribution, and reproduction in any medium, provided the original author and source are credited. 